\title{
Perception and Expectations of Newly Enrolled Students from The Optometry Profession: A Study from Northern India
}

\author{
Anam Ali ${ }^{1}$, Mosaib Omaer ${ }^{2}$, Pradeep Agarwal ${ }^{3}$, Lokesh Chauhan ${ }^{4}$
}

\begin{tabular}{l} 
ARTICLE INFO \\
\hline Article History: \\
Received 25.09.2021 \\
Received in revised form \\
30.01 .2022 \\
Accepted \\
Available online 01.01 .2023
\end{tabular}

\begin{abstract}
This study provides information regarding the perception and expectations of newly enrolled optometry students in the optometry profession. It's a questionnaire-based study. The data was collected through an online questionnaire from students of different optometry colleges. 152 students responded to the questionnaire, majority of students 91(59.9\%) selected Optometry as a first choice. The majority of students 93(61.2\%) know that optometrist can work as a researcher. 80 (52.6\%) feels they should get a salary between 25000 - 35000 Indian national rupees (339.63 - 475.48 US\$) after completing the four years optometry programme. Our study shows newly enrolled students are aware about optometry profession and its scope however areas like salary expectations and language skills are concerned areas in students.
\end{abstract}

CCTUARA Journal. All rights reserved

Keywords:

Optometry, education, students, awareness, regulatory bodies

\section{INTRODUCTION}

Council of Optometry (WCO) has defined optometry as:"A healthcare profession that is autonomous, educated and regulated (licenced/registered), an optometrist is the primary healthcare practitioner of the eye and visual system who provide comprehensive eye and vision care, which includes refraction and dispensing, detection and diagnosis and management of disease in the eye, and the rehabilitation of conditions of the visual system" (Masnick \& Gavzey, 2004). To be an optometrist, one must be graduate from an optometry school/college/university, the total duration of the undergraduate optometry programme is of 4 to 5 years depending on the country of study (De Souza et al., 2012).

Optometry services diversify across different country. An optometrist does practise in multiple areas like hospital/clinic-based practise, academics, optical retail, eye health research, administration, marketing, and independent private practice (Thite, Jaggernath, Chinanayi, Bharadwaj, \& Kunjeer, 2015). The scope and practise of Optometry in India are still poorly defined and a large number of people are not aware about the role and responsibility of optometrist in the healthcare system even optometry profession do not have a centralised regulatory body as pharmacy, nursing or dental profession has (Dubey, 2019). There are no specific practise guidelines, licences, or registration for eye care professionals such as optometrist, refractionist, orthoptists, ophthalmic assistants, and ophthalmic technicians (Awan, 2019). All these professions perform a comprehensive eye examination and dispense spectacles and contact lenses without any specific regulatory structure (Chan, 2015). Whereas in developed countries the governments and/or law regulates the optometry education and provides practise guidelines. Optometrists in developed countries such as the United Kingdom, Spain, Ireland, the United States of America, Canada, Australia, and European countries play an integral role in eye care practise (Smith, 2002). These factors make optometry not a very popular choice among senior secondary (is also often called Higher Secondary or Senior Secondary, or simply the "10+2" stage, in which students can study after initial 10 years of junior sch ool education) passed out students, as a future career choice in India. The increasing burden of blindness (39.365 million) and visual impairment (285.389 millions)is still one of the major public health challenges globally (Dandona,1998; Pascolini \& Mariotti, 2012). More eye-care professionals with different levels of skills are required to deal with the present need for eye care and optometry is one such profession that is essential to cater the needs of

\footnotetext{
${ }^{1}$ Optometry, Intern Optometrist, Department of optometry and visual sciences, CL Gupta Eye Institute, Ram Ganga Vihar, Phase II (Ext) Moradabad-244001 India. alianam194@gmail.com, orcid.org/ 0000-0001-6119-2518

2.M. Optometry, Faculty Optometrist, Department of optometry and visual sciences, CL Gupta Eye Institute, Ram Ganga Vihar, Phase 2(Ext) Moradabad-244001 India. mossab@clgei.org, orcid.org/ 0000-0001-7272-6773

3.MS Ophthalmology, Consultant Ophthalmologist, Department of Pediatric ophthalmology, Strabismus and Neuro-Ophthalmology, CL Gupta Eye Institute, Ram Ganga Vihar, Phase II (Ext) Moradabad-244001 India. drpradeep@clgei.org, orcid.org/ 0000-0002-8948-6734

${ }^{4}$ M.Sc, Research Associate, Department of Clinical and Public Health Research, CL Gupta Eye Institute, Ram Ganga Vihar, Phase II (Ext) Moradabad-244001 India. lokesh.chauhan@rediffmail.com, orcid.org/ 0000-0001-8274-1491
} 
primary eye health care (Adepoju, Ayanniyi, Pam \& Akanbi, 2011). But even after being a well-established profession in many developed countries such as the United Kingdom, Spain, Ireland, United States, Canada, Australia, and many European countries, optometry profession and practise lacks acceptance in many developing countries (Ackland, 2012). According to the India Vision Institute report, about 164 institutions providing optometry diploma or degree courses in India and near to 49,000 optometrists are available in the country, globally there are about 358 teaching institutes and 250,000 optometry specialists according to WCO. India contributes around $19.6 \%$ of the optometrists in the world as per the above data (Venugopal, Lal, Shirodker, Kanojiya \& Kaushal, 2020). In preparing the well competent and qualified optometrists in the country, student selection in four years bachelor optometry programme is an important component the selection process requires the development and implementation of strategies that ensure that the most appropriate and willing students are selected into the programme (Chan V. F,2015). Students who select their courses with an exact career plan are much more likely to have educational success (Duguet, Mener, \& Morlaix, 2016). Similarly, college students who are satisfied with their selected programme of study have been much more likely to continue in their respective careers (Van der Zanden, Denessen, Cillessen, \& Meijer, 2018). Since it has been reported that due to the absence of a governmental regulatory body very fewer students opting for optometry as a career, so we wanted to assess the response of students as per the set questionnaire to those students who already have been opted for optometry and in the first semester of the programme (Chan, 2015).

The objective of the study is to provide baseline information about the awareness, perception, and expectation of newly enrolled optometry students from the optometry profession. We feel the knowledge generated from this study will give a basic picture to key decision-makers and educators concerning the support needs of future students in neglected areas, creating awareness strategies for students, and developing informed human resources which would be more efficient in-service delivery in eye health care.

\section{Aim of the Study}

The knowledge generated from this study will give a basic picture to key decision-makers and educators concerning the support needs of future students in neglected areas, creating awareness strategies for students, and developing informed human resources which would be more efficient in-service delivery in eye health care.

\section{METHOD}

This is a questionnaire-based study, where the data was collected online. The questionnaire was adapted from a previous study with some modifications (Chan, 2015). The questionnaire consists of a total of 18 questions which are further grouped into four-parts consisting of demographic characteristics, selfreported skill, perceptions about the optometry profession, and expectations from the optometry profession. An anonymous questionnaire limited to one response was developed in the google form and the google form link of the questionnaire was shared with the optometry department in charges of the different optometry colleges and the colleges in charges have shared the questionnaire link with the first semester students of the optometry programme in their respective colleges. The college incharge was also informed about the study objectives and methodology, they were also further informed to share the link with the only students who are in the first semester and not completed more than three months in the first-semester study. Data of the only students who have responded to all the questions of the questionnaire were included and the students who have responded to their last education/degree as Diploma in optometry have been excluded from the study. Data that were received after 31st October 2019 were excluded. Consent was obtained from each participant. 152 participants responded to the questionnaire of which $83(54.6 \%)$ were female and $69(45.4 \%)$ were male. To ensure that student perceptions were not biased, the data were collected from the first semester students(August 2019 to October 2019)of B. optometry as the common minimum optometry curriculum (CMOC) adopted by Indian universities does not contain optometryrelated subjects In the first-semester curriculum and the only exposure students have the basic pure medical science subjects.3Responses were collected from google form and entered into Microsoft MS Excel 2011 and analysed by SPSS V20 software.

\section{Data Analyses}

All analysis was performed using SPSS version 20, frequencies, and percentages $n(\%)$ were calculated for qualitative variables. The qualitative variables were compared with the Chi-square test. Statistical significance was considered as $\mathrm{P}<0.05$. 


\section{FINDINGS}

152 participants responded to the questionnaire of which $83(54.6 \%)$ were female and $69(45.4 \%)$ were male. The majority of students $78(51.3 \%)$ belonging from urban areas while $74(48.7 \%)$ are from rural parts of the country who have to travel from rural areas to attend optometric programmes as institutions are situated in urban areas. The majority of the students $(50.7 \%)$ joined the bachelor optometry programme immediately after completing their senior secondary and the remaining students join after a gap of 1 year, 2 years and few $(7.2 \%)$ with a gap of three or more years. (Table-1)

Table 1: Demographics of students responded to the questionnaire

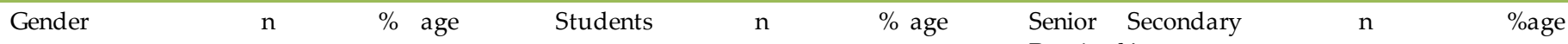

\begin{tabular}{|c|c|c|c|c|c|c|c|c|}
\hline Female & 83 & 54.6 & Urban & 78 & 51.3 & 2019 & 77 & 50.7 \\
\hline \multirow[t]{3}{*}{ Male } & 69 & 45.4 & Rural & 74 & 48.7 & 2018 & 50 & 32.9 \\
\hline & & & & & & 2017 & 14 & 9.2 \\
\hline & & & & & & Before 2017 & 11 & 7.2 \\
\hline Total & 152 & 100 & & 152 & 100 & & 152 & 100 \\
\hline
\end{tabular}

A good command of the English language is important because, the course materials for optometry like reference books, educational materials, and online resources are predominantly written in English. For completing assignment dependency on online resources, for example, maybe dependant on the Internet, suggesting that computer skills are equally important. Concerning this we also asked about English and computer skills (Table 2) on, average, good and poor option responses. The majority of students placed them on average to good category in English and Hindi reading, writing, and speaking skills respectively where Hindi writing skill showing a significant statistical difference, $\mathrm{p}=0.028$ ( $\mathrm{p}<0.05$ level of significance) between female and male students. In computer skills, like basic knowledge of Microsoft MS office, able to send and operate email and internet skills, students identified themselves with an average to good in email management and internet skills, however in MS office skill majority of students identified themselves with average to poor skill (Table -2). Significant difference between females and males has been observed in internet skill, $\mathrm{p}=0.035(\mathrm{p}<0.05)$ (Table - 2$)$.

Table 2: Self perceived skills and comparison of skills according to gender

\begin{tabular}{|c|c|c|c|c|c|c|c|c|c|c|c|}
\hline Skills & $\begin{array}{l}\text { Female } \\
\mathrm{n}(\%)\end{array}$ & $\begin{array}{l}\text { Male } \\
\mathrm{n}(\%)\end{array}$ & P-Value & Skills & $\begin{array}{l}\text { Female } \\
\mathrm{n}(\%)\end{array}$ & $\begin{array}{l}\text { Male } \\
\mathrm{n}(\%)\end{array}$ & P-Value & Skills & $\begin{array}{l}\text { Female } \\
\mathrm{n}(\%)\end{array}$ & $\begin{array}{l}\text { Male } \\
\mathrm{n}(\%)\end{array}$ & P-Value \\
\hline \multicolumn{4}{|c|}{ English reading } & \multicolumn{4}{|c|}{ English writing } & \multicolumn{4}{|c|}{ English speaking } \\
\hline Good & $53(63.9 \%)$ & $31(44.9 \%)$ & & Good & $48(57.8 \%)$ & $29(42.0 \%)$ & \multirow{3}{*}{0.145} & Good & $24(28.9 \%)$ & $15(21.7 \%)$ & \multirow{3}{*}{0.54} \\
\hline Average & $29(34.9 \%)$ & $36(52.2 \%)$ & & Average & $33(39.8 \%)$ & 37 (53.6\%) & & Average & $51(61.4 \%)$ & $45(65.2 \%)$ & \\
\hline Poor & $1(1.2 \%)$ & $2(2.9 \%)$ & 0.06 & Poor & $2(2.4 \%)$ & $3(4.3 \%)$ & & Poor & $8(9.6 \%)$ & $9(13.0 \%)$ & \\
\hline \multicolumn{4}{|c|}{ Hindi reading } & \multicolumn{4}{|c|}{ Hindi Writing } & \multicolumn{4}{|c|}{ Hindi speaking } \\
\hline Good & $54(65.1 \%)$ & $37(53.6 \%)$ & \multirow{3}{*}{0.35} & Good & $49(59.0 \%)$ & 27 (39.1\%) & \multirow{3}{*}{$0.028^{*}$} & Good & $58(69.9 \%)$ & $44(63.8 \%)$ & \multirow{3}{*}{0.342} \\
\hline Average & $22(26.5 \%)$ & $25(36.2 \%)$ & & Average & $25(30.1 \%)$ & $26(37.7 \%)$ & & Average & $20(24.1 \%)$ & $23(33.3 \%)$ & \\
\hline Poor & $7(8.4 \%)$ & $7(10.1 \%)$ & & Poor & $9(10.8 \%)$ & $16(23.2 \%)$ & & Poor & $5(6.0 \%)$ & $2(2.9 \%)$ & \\
\hline \multicolumn{4}{|c|}{ Microsoft MS Office skill } & \multicolumn{4}{|c|}{ Email skill } & \multicolumn{4}{|c|}{ Internet Skill } \\
\hline Good & $\begin{array}{c}11 \\
(13.3 \%)\end{array}$ & $\begin{array}{c}18 \\
(26.1 \%)\end{array}$ & & Good & $22(26.5 \%)$ & $21(30.4 \%)$ & & Good & $36(43.4 \%)$ & $41(59.4 \%)$ & \\
\hline Average & $\begin{array}{r}49 \\
(59.0 \%)\end{array}$ & $\begin{array}{r}34 \\
(49.3 \%)\end{array}$ & 0.132 & Average & $38(45.8 \%)$ & $37(53.6 \%)$ & 0.222 & Average & $39(47.0 \%)$ & $27(39.1 \%)$ & $0.035^{*}$ \\
\hline 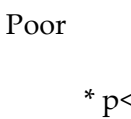 & $5^{23}$ & $\begin{array}{r}17 \\
(24.6 \%)\end{array}$ & & Poor & $23(27.7 \%)$ & $11(15.9 \%)$ & & Poor & $8(9.6 \%)$ & $1(1.4 \%)$ & \\
\hline
\end{tabular}


A higher number of students $91(59.9 \%)$ selected Optometry as a first choicewhile43(28.3\%) students were having MBBS (Bachelor of Medicine and Bachelor of Surgery is the undergraduate medical programme in India. Medical aspirants across the country who aspire to become practising doctors in the field of allopathic medicine have to pursue the MBBS programme as their first choice. Bachelor of dental surgery (BDS),nursing, pharmacy and traditional undergraduate programme (B. A, B.Sc., B. Com) was the first choice in $5(3.3 \%), 5(3.3 \%), 4(2.6 \%), 4(2.6 \%)$ students respectively as a choice of the undergraduate programme (Table-2). 144 (94.7\%) participants were aware as a senior secondary school certificate with science subjects required to get admission in the bachelor of optometry programme. When asked about optometrists' scope as a researcher,93(61.2\%) students were responded as a "yes" while 52(34.2\%) students responded as "can't say". Majority of students (126, $82.9 \%$ ) aware of the fact that optometrist, ophthalmologist, and opticians are not the same, while 7 $(4.6 \%)$ students feel all the three are the same profession (Table-3).

Table 3: Perception of the optometry profession in students

\begin{tabular}{|c|c|c|c|c|c|c|}
\hline $\begin{array}{l}\text { What was your first choice } \\
\text { of undergraduate (UG) } \\
\text { program? }\end{array}$ & 91 (59.9\%) & $\begin{array}{l}\text { *MBBS } \\
43(28.3 \%)\end{array}$ & ${ }^{* *} \mathrm{BDS}$ & $5(3.3 \%)$ & $4(2.6 \%)$ & $\begin{array}{c}{ }^{* *} \text { Conventiona } \\
\text { Courses \& othe1 } \\
4(2.6 \%)\end{array}$ \\
\hline $\begin{array}{l}\text { What is the educational } \\
\text { eligibility to pursue } \\
\text { Bachelor of Optometry } \\
\text { program? }\end{array}$ & $\begin{array}{l}\text { Senior } \\
\text { Secondary }\end{array}$ & 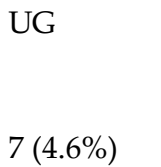 & $\begin{array}{l}P G \\
1(0.7 \%)\end{array}$ & & & \\
\hline $\begin{array}{l}\text { Are Optometrist do or } \\
\text { participate in research } \\
\text { work? }\end{array}$ & $\begin{array}{l}\text { No } \\
7(4.6 \%)\end{array}$ & $\begin{array}{l}\text { Yes } \\
93(61.2 \%)\end{array}$ & $\begin{array}{c}\text { Can't Say } \\
52 \\
(34.2 \%)\end{array}$ & & & \\
\hline $\begin{array}{l}\text { Are Optometrist, } \\
\text { Ophthalmologist and } \\
\text { Opticians being same } \\
\text { professionals? }\end{array}$ & $\begin{array}{l}\text { No } \\
126(82.9 \%)\end{array}$ & $\begin{array}{l}\text { Yes } \\
7(4.6 \%)\end{array}$ & $\begin{array}{l}\text { Can't Say } \\
19(12.5 \%)\end{array}$ & & & \\
\hline
\end{tabular}

About half of students 80 (52.6\%) feel they should get a salary range between 25000 - 35000 Indian nation rupees(339.63 US\$ - 475.48 US\$)as a fresher optometrist. 122 (80.3\%) participants responded as the availability of government jobsfor Optometry professionals (Table- 4). To improve quality of life by prescribing glasses and contact lenses, maintain eye health, promote eye health, and provide affordable eye care are identified as major roles of optometrist by students (Table -4 ).

Table 4: Students' expectation from the optometry profession

$\begin{array}{lll}\text { Salary expectation per month after compilation of study } & \mathrm{n} & \% \text { age } \\ 10000-20000 & 14 & 19.2 \\ 25000-35000 & 80 & 52.6 \\ 40000-50000 & 37 & 24.3 \\ >50000 & 19 & 12.5 \\ \text { No Response } & 2 & 1.3 \\ \text { Are government jobs available in the Optometry profession? } & \mathrm{n} & \% \text { age } \\ \text { No } & 1 & 0.7 \\ \text { Yes } & 122 & 80.2 \\ \text { Cannot say } & 29 & 19.1\end{array}$

\section{DISCUSSION AND SUGGESTIONS}

This study aims to provide baseline information about the perception and expectation of newly enrolled optometry students, the demographic distribution of the study respondents showed a greater number of females than males. This is opposite to the study by Eze 2016 in which male respondents are more than 
females (Eze, Obiekwe, \& Aguwa, 2016), this could be because traditionally female students are more oriented towards medical science courses.(Robinson, 2003). It is also shown in the study that there are more students from urban area compare to rural, there are many factors which can influence rural population such as the education level of parents, the poverty rate is higher in rural population and the locations of institutes, we believe this could be a reason for the less enrolment of students from rural areas (Mashige \& Oduntan, 2011). In this respect, our study also shows similarity with a similar study done by Chan et al. (2015). The majority of students joined the optometry programme immediately after completing their $10+2$ education, while the remaining students joined after a gap of one or two years as a similar result was found in the previous study by Chan et al. (2015) in Mozambique. Our result also reflects that most of the students had the first choice of study optometry as an undergraduate programme but in a very similar previous study conducted by Chan et al has shown only one student selected optometry as the first choice. The increasing number of students opting for optometry courses as their first choice in our study shows that new senior secondary passed students are aware of the optometry profession, this could be due to increasing awareness of the optometry profession as well as more job opportunity, flexible work hours, and potential to earn good starting salary in this allied health profession (Mashige \& Oduntan, 2011). In our study, about $82 \%$ of participating students were aware of the fact that the optometrist, ophthalmologist, and opticians are not the same professionals but in -a previous study by Eze et al. (2016) showed that only $55.6 \%$ of the respondents reported awareness of the differences between the ophthalmologists and optometrists (Eze et al., 2016), this again shows students in our study are more aware of different eye health care profession. There is an increasingly widespread perception within higher education that the language and literacy skills of students of both English-speaking backgrounds and non-English speaking backgrounds are in a state of decline (Murray, 2010). Therefor concerning English language skills our data showed most of the students feel they have average to good English reading and writing skills and poor English speaking, similar to those as reported by Chan et al. (2015). Females tend to rate their skills in languages higher than males in both languages English and Hindi. This is similar to Ving Fai Chan et al study conducted in Mozambique6 concerning the English language. Salary is an important consideration in choosing any profession and the response from the newly enrolled student suggests that a newly passed optometry graduate should earn a mean salary of about 25000-35000 Indian national rupees ( 339.63 - 475.48 US\$). Whereas the starting average salary for Optometrist is 16000 INR (217.36US\$) in India. This shows a higher expectation of starting salary, then what is currently being offered in India, this is similar to a previous study Oduntan et al carried in South Africa (Oduntan, Louw \& Moodley, 2007), where, also participants showed a higher expectation of the initial salary. One of the major limitations our study has, is student biases in self-reporting for perceptions and perceptions as they already have completed one to three months in the first semester of the optometry programme and the other limitation is the short sample size, therefore a study in students of the senior secondary school with large sample size would give a more realistic students awareness, expectations, and perception of the profession of optometry. The training and scope of practise of optometry in India have been somewhat fragmented in the past but now have, made tremendous progress. With new optometry institutions establishment and increase inclusion of optometry undergraduate programme in the universities offered courses the awareness is to be going to increase in the coming times, however, the academic institutions need to full fill the expectations of students from the profession in maintaining a long-term interest of students in this primary eye health care profession. Salary expectations and language skills should be a concern area to the academicians and the policymakers respectively for taking necessary steps, so that language skills should be met and passed out students' expectations with the optometry profession should be met.

\section{REFERENCES}

Ackland, P. (2012). The accomplishments of the global initiative VISION 2020: The right to Sight and the focus for the next 8 years of the campaign. Indian Journal of Ophthalmology, 60(5), 380-386. https://doi.org/10.4103/0301-4738.100531

Adepoju, F. G., Ayanniyi, A. A., Pam, V. \& Akanbi, T. B. (2011). Human resource development for vision 2020 in developing countries: A change from absolute numbers. European Journal of Ophthalmology, 21(6), 820-825.https://doi.org/10.5301/EJO.2011.6434

Awan, H. (2019). Assessment of eye health services: A health systems approach. In book: Innovative Approaches in the Delivery of Primary and Secondary Eye Care (pp.181-194 181-194). https://doi.org/10.1007/978-3- 
319-98014-0_12.

Chan, V. F., Loughman, J., Moodley, V. R., Bilotto, L. \& Naidoo, K. (2015). Student educational background, perceptions and expectations toward optometry: An emerging eye health profession in Mozambique. Optometric Education, 40(2).

Dandona R. (1998). Optometry and eye care in India. Indian Journal of Ophthalmology, 46(3).

De Souza, N., Cui, Y., Looi, S., Paudel, P., Shinde, L., Kumar, K., ... Holden, B. (2012). The role of optometrists in India: An integral part of an eye health team. Indian Journal of Ophthalmology, 60(5), 401405. https://doi.org/10.4103/0301-4738.100534.

Dubey, G. (2019). A cross-sectional survey evaluatıng the awareness about the optometry profession among residents in areas of Saifai. Clin Exp Optom, 98(5). doi: 10.1111/cxo.12291.

Duguet, A., Mener, M. L. \& Morlaix, S. (2016). The key predictors of success in university in France: What are the contributing factors and possible new directions in educational research? International Journal of Higher Education, 5(3), 222-235.https://doi.org/10.5430/ijhe.v5n3p222

Gudlavalleti, V. S., Shukla, R., Batchu, T., Malladi, B. V. S. \& Gilbert, C. (2018). Public health system integration of avoidable blindness screening and management, India. Bulletin of the World Health Organization, 96(10), 705-715.https://doi.org/10.2471/BLT.18.212167

Eze, B., Obiekwe, O., \& Aguwa, E. (2016). Public's knowledge of the differences between ophthalmologists and optometrists: a critical issue in eye care service utilisation. (September). https://doi.org/10.18240/ijo.2016.09.18

Kumar, N. (1976). Role of optometrist in ophthalmic practice. Indian journal of ophthalmology, 24(1), 41-42.

Mashige, K. P. \& Oduntan, O. A. (2011). Factors influencing South African optometry students in choosing their career and institution of learning. African Vision and Eye Health, 70(1), 21-28. https://doi.org/10.4102/aveh.v70i1.90

Masnick, K. \& Gavzey, R. (2004). What is an optometrist? Optometry and Vision Science, 81(5), 289-290. https://doi.org/10.1097/01.opx.0000134897.45038.e4

Murray, N. L. (2010). Conceptualising the English language needs of first year university students. 1(1), 55-64.

Oduntan, A. O., Louw, A. \& Moodley, V. R. (2007). Perceptions, expectations, apprehensions and realities of graduating South African optometry students (PEAR study, 2006). African Vision and Eye Health, 66(3), 94-108.https://doi.org/10.4102/aveh.v66i3.237

Pascolini, D. \& Mariotti, S. P. (2012). Global estimates of visual impairment. British Journal of Ophthalmology, 96(5), 614-618.https://doi.org/10.1136/bjophthalmol-2011-300539

Robinson, M. (2003). Student enrollment in high school AP sciences and calculus: How does it correlate with STEM careers? Bulletin of Science, Technology and Society, 23(4), 265-273. https://doi.org/10.1177/0270467603256090

Smith, D. P. (2002). The 75th anniversary of the World Council of Optometry. Clinical and Experimental Optometry, 85(4), 210-213. Retrieved from http://onlinelibrary.wiley.com/doi/10.1111/j.14440938.2002.tb03039.x/pdf

Thite, N., Jaggernath, J., Chinanayi, F., Bharadwaj, S. \& Kunjeer, G. (2015). Pattern of optometry practice and range of services in India. Optometry and Vision Science, 92(5), 615-622. https://doi.org/10.1097/OPX.0000000000000587

van der Zanden, P. J. A. C., Denessen, E., Cillessen, A. H. N. \& Meijer, P. C. (2018). Domains and predictors of first-year student success: A systematic review. In Educational Research Review, 23. https://doi.org/10.1016/j.edurev.2018.01.001

Venugopal, D., Lal, B., Shirodker, S., Kanojiya, R. \& Kaushal, R. (2020). Optometry students' perspective on optometry in suburban Western India: A qualitative study. Journal of Optometry. https://doi.org/10.1016/j.optom.2020.02.003 